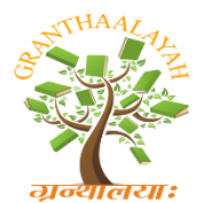

\author{
INTERNATIONAL JOURNAL OF
GRANTHAALAYAH \\ A knowledge Repository
}

Management

\title{
EFFECT OF WORK ENVIRONMENT TO EMPLOYEE PERFORMANCE IN PT ABADI MOTOR INDONESIA
}

\author{
Nahason Sitohang *1 \\ ${ }^{* 1}$ STIE YPBI, Jakarta, Indonesia
}

\begin{abstract}
Effect of Work Environment on Employee performance at PT. Abadi Motor Indonesia. The purpose of this study is to determine how much influence the work environment has on employee performance. The variable used is the variable $\mathrm{X}$ as an independent variable that is the work environment and the variable $\mathrm{Y}$ as the dependent variable that is, employee performance. Work environment that is something that is around workers and can influence them in carrying out the tasks that are charged, Performance is the result or level of overall success of a person during a certain period while the place that is the object of this research is PT. Abadi motor Indonesia The research method used in this study is qualitative. The sampling technique used in this study was a random sampling technique with a total sampling of 30 respondents. The results of the study are: Linear regression $+y=15.21+0.65 X$, product moment correlation test of $r=0.70$, this means that this study has a strong influence. Determination coefficient of $49.5 \%$, this means that the work environment contributes to employee performance by $49.5 \%$ and the remaining $50.5 \%$ is determined by other variables not included in this study, hypothesis test $t$ count $=5.245$, and table 2.048 , then $t$ count $>t$ table means that there is an influence of the work environment on employee performance.
\end{abstract}

Keywords: Work Environment and Employee Performance.

Cite This Article: Nahason Sitohang. (2020). "EFFECT OF WORK ENVIRONMENT TO EMPLOYEE PERFORMANCE IN PT ABADI MOTOR INDONESIA." International Journal of Research - Granthaalayah, 8(2), 19-27. 10.29121/granthaalayah.v8.i2.2020.180.

\section{Introduction}

\subsection{Background}

A company in carrying out its activities, both companies engaged in manufacturing, trade and services will try to achieve the goals that have been set previously. One important thing is that the success of various activities within the company in achieving its goals one of which is the comfort of the work environment. The comfort of the work environment of employees can trigger employees to work better so that work productivity can be achieved to the maximum. A good work environment is expected to be able to spur high employee work performance. A good work 
environment will greatly affect the work performance of employees, aspects that affect the work environment include lighting arrangements, work levels, noise, good air circulation, especially in the work environment, cleanliness of the work environment, and security of employee belongings.

The work environment has an influence on the performance of company employees in an effort to complete the tasks that are charged to the kapadanya which ultimately affect the performance of employee performance, a good environment will improve work, and vice versa if the work environment is less calm, will be able to increase the level of mistakes they do. A company that operates in an environment cannot deny that in addition to business activities they are also involved with the environment around the company, therefore every company needs to understand deeply about any environment that is directly or indirectly related to its work activities so that employee performance can achieve at the maximum point.

performance is basically a universal concept that applies to all systems, because every activity requires performance in its implementation. A comparison between output and input or output: input. Input is often limited by labor input, while output is measured in physical unity of form and value. Although sometimes performance is seen as more incentive for users of conversion sources such as labor and machinery which if measured correctly will show an appearance or efficiency. From the description above the researcher wants to find out how much influence the work environment has on improving employee performance, for this reason the researcher takes the title of the study: "EFFECT OF WORK ENVIRONMENT ON EMPLOYEE

\section{Theoretical Basis}

As a basis for thinking in comparing existing theories with facts, the writer will use several theories in order to solve the problems that have been formulated, so that it is more directed and clear in the delivery of concepts in this thesis.

\subsection{Work Environment}

\subsubsection{Definition of the Work Environment}

Understanding the work environment according to Armstrong (Bagus Kisworo, 2012: 75), the work environment consist of the system of work, the design of jobs, working conditions, and the ways in which people are treated at work by their managers and co-workers. The work environment consists of work systems, job designs, working conditions and the ways in which people are treated at work with their managers and their colleagues. According to Nitisemito (1996: 109), is something that is around workers and can influence them in carrying out the tasks assigned. According to Sedarmayati (2001: 1), defining the work environment is the overall tools and materials faced, the surrounding environment in which a person works, his work methods, and his work arrangements both as individuals and as groups.

Based on the various opinions above it is concluded that the work environment is a condition where employees work in a company that can directly and indirectly affect the physical and psychological conditions of employees so that the work environment can be said to be good if employees can work optimally, calmly, and have high productivity. 


\subsubsection{Indicators of the Work Environment Comfortable}

Broadly speaking, the type of work environment is divided into 2 namely: 1) physical work environment, and 2) non-physical work environment.

\section{1) Physical Work Environment}

The physical work environment is all that is around the workplace that can affect employees both directly and indirectly (Sedarmayanti, 2001: 21). According to Nitisemito (1996: 110), several things that can affect the enthusiasm and excitement of work include the following: (1) Coloration; (2) Cleanliness; (3) Air Exchange; (4) Information; (5) Music; (6) Security; (7) Noise. In addition, according to Liang Gie (2000: 210-220), there are four things that greatly affect efficiency in office work, namely: (1) Light; (2) Color; (3) Air; (4) Sound.

Based on the description of several experts regarding the indicators of the physical work environment above, it can be concluded that the indicators of the physical work environment include (1) Room coloring; (2) Cleanliness; (3) Air exchange; (4) Information; (5) Security; (6) Noise.

\section{a) Room Coloring}

According to Nitisemito (1996: 110), color selection can affect the mood and morale of employees. Space coloring should use cool and soft colors to be seen, such as light brown, beige, light gray, light green, etc. In addition to the color that must be considered, the color composition in a room must also be considered because it could be that the color composition that is not suitable can cause discomfort when looking at it so that it will interfere with employees. For example the blue color is aligned with the color purple will look gloomy.

Coloring is not only about coloring the walls of the workspace, but also the uniform color, the color of work equipment, and objects around the workplace of employees as well, therefore coloring is a very important element and has an indirect impact on employees. According to McShane (Badri, 2006: 214), coloring has an impact on positive and negative psychology for employees in terms of productivity, fatigue, morals, behavior and tension. In line with the opinion above Liang Gie (1996: 216), states that the color will affect the mental state of employees, by using the right color on the walls of the room and other tools, the excitement and peace of work of the employees will be maintained.

According to Nitisemito (1996: 110), colors have different properties that can stimulate the souls of people who see it. The following are the properties of these colors: (1) Red: provides stimulation, exerts heat, and can vibrate the souls and feelings of those who see it; (2) Yellow: arouse joy and give bright, majestic, and wise light; (3) Blue: creates a sense of calm, peace, and clean; (4) Orange: is the hottest color, has extraordinary strength and energy, giving rise to life and enthusiasm. (5) Green: is the color of plants giving rise to a cool and fresh taste; (7) Violet color: creates a high vibration from the secret and depicts an uncontrollable power.

\section{b) Cleanliness}

According to Nitisemito (1996: 10), for a normal person room cleanliness is one of the most important factors that can affect the enthusiasm in working. Every institution and organization is 
expected to always maintain the cleanliness of the work environment because in addition to affecting health but can also affect the mental condition of its employees. Cleanliness is not only the responsibility of cleaning staff but all employees in the institution, so that each institution is expected to be able to uphold strict discipline regarding cleanliness.

\section{c) Air Exchange}

Air exchange is one thing that should be considered in an institution because most of the time will be spent by employees in their work area. Air exchange greatly determines the physical fitness of employees (Nitisemito, 1996: 193). Air that does not experience exchange will increase CO2 gas, not fresh and the room temperature will be hot. The sufficient air exchange rate is 1.67 cubic meters (Badri, 2006: 220). Ventilation is a tool to regulate.

Air exchange which is usually widely used because besides saving costs but also saving energy. In addition to ventilation, air condition (AC) is a tool that is now widely used by companies and institutions to regulate room temperature and air cleanliness, using air conditioning can cause coolness so as to eliminate fatigue for employees (Liang Gie, 1996: 115). AC also serves to clean the air because $\mathrm{AC}$ is currently equipped with the ability to clean air from germs, dust and dirt (Badri, 2006: 220).

\section{d) Lighting}

Lighting is a very important factor because it will affect employee productivity, fatigue in the eyes will increase if the level of light in the workplace is not appropriate and will cause employees to experience tension in their eyes, thus affecting their physical (Badri, 2006: 208). Lighting is not limited to lighting that uses electricity, but also lighting using sunlight. In Indonesia, companies or institutions are more dominant in using sunlight as a means of lighting, besides saving energy, it is also healthy as long as it is within the limits of reasonableness in receiving its rays. Therefore, an effective lighting system must take into account the quality and quantity of light in accordance with the task, the room, and the employees themselves (Badri, 2006: 208).

\section{e) Security}

Security here according to Nitisemito (1996: 116), is divided into two, namely the security of personal property and personal safety of employees. Security for private property such as employee vehicles left in the parking lot so that employees cannot supervise directly, if the parking space is not safe will cause their own anxiety for employees that cause enthusiasm and excitement at work decreases and as a result of these things employee productivity will decrease. Furthermore, employee safety is often interpreted as work safety. Hazardous work employees should use appropriate standards that can reduce the risk of accidents in the workplace.

According to Badri (2006: 223), security has two dimensions, namely the security of physical goods and the security of important information (documents and records) which if lost will affect the course of company activities. Here are some suggestions related to security in the office according to Rowh (Badri, 2006: 223):

- Use of a shrendder.

- Use of computer security, both desktop and laptop.

- Use of timekeepers to prevent employees from stealing work time.

- Integrated security system. 
- Use of a password on a computer.

\section{f) Noise}

Noise according to the Decree of the Minister of Health of the Republic of Indonesia Number 1405 / MENKES / SK / XI / 2002 is the occurrence of unwanted noise that disturbs or endangers health. The procedure for removing the noise according to the above Decree is by reducing, blocking, moving, maintaining, planting trees, making artificial hills, and others.

Noise is one of the factors that will interfere with employees in terms of concentration so as to reduce employee productivity. According to Shomer (Badri, 2006: 216), repeated noise will cause physical and psychological disorders such as temporary or permanent hearing loss, physical and mental fatigue, anxiety, tension that can increase blood pressure and metabolism, and in a time that long time can cause serious health problems.

\section{2) Non-Physical Work Environment}

According to Sadarmayanti (2001: 31), non-physical work environment is all conditions that occur related to work relationships, both relationships with superiors and fellow co-workers, or relationships with subordinates. This non-physical environment is also a group of work environments that cannot ignored.

According to Alex Nitisemito (2000: 171-173) the company should be able to reflect conditions that support cooperation between the levels of superiors, subordinates and those who have the same job status in the company. The conditions that should be created are a family atmosphere, good communication, and self-control.

Suryadi Perwiro Sentoso (2001: 19-21) quoting Prof.'s statement Myon Woo Lee, the originator of the W theory in Human Resource Management, said that the company management should build a climate and work atmosphere that could arouse a sense of family to achieve common goals. The company management should also be able to encourage initiative and creativity. Conditions like these that further create enthusiasm to unite in corporate organizations to achieve goals.

\section{3) Benefits of the Work Environment}

According to Ishak and Tanjung (2003), the benefits of the work environment are creating work passion, so that productivity and work performance increase. Meanwhile, the benefits gained from working with motivated people are that the work can be completed properly, which means that the work is completed according to the correct standard and on a specified time scale. His work performance will be monitored by the individual concerned, and will not cause too much supervision and his fighting spirit will be high.

\section{4) Definition of Performance}

An assessment of individual employee performance is increasingly important when the company will reposition employees. This means that companies must know what factors affect performance. The results of the analysis will be useful to create an optimal HR development program. Individual performance will reflect the degree of competency of a company. Good performance is performance that follows procedures or procedures according to established standards. However, in the performance must have several criteria in order to increase productivity so that what is 
expected can run according to what is desired. To improve good performance, introspection must be done in order to achieve better performance in the future, working according to position, portion, and job respectively.

Performance is the result or overall level of success of a person during a certain period in carrying out the task compared with various possibilities, such as work standards, targets or targets or criteria that have been predetermined and agreed upon together.

Here are some definitions of performance according to the Experts:

- Performance according to Anwar Prabu Mangkunegara (2000: 67)

- Performance (work performance) is the result of work in quality and quality achieved by an employee in carrying out their duties in accordance with the responsibilities given to him.

- Performance according to Malayu S.P. Hasibuan (2001: 34)

- Performance (work performance) is a result of work achieved by a person in carrying out the tasks assigned to him based on skill, experience and sincerity as well as time.

\section{5) Factors That Affect Performance}

Factors that affect performance, according to Mathis and Jackson (2006: 113-114), the performance of employees is an initial organizational success to achieve its goals. There are 3 main factors that affect employee performance, namely:

\section{a) Individual Ability}

The individual abilities of these employees include talents, interests, and personality factors. The level of raw material skills possessed by someone in the form of knowledge, understanding, ability, interpersonal skills, and technical skills. Thus the possibility, an employee will have a good performance. If the employee has good skills, the employee will produce good performance as well.

\section{b) Business Is Poured Out}

The effort that is expended by employees for the company is motivation, work ethics, presence. The level of effort is a picture of motivation shown by employees to get the job done well. From that, even if employees have the level of skills to do the work, but will not work well if only a little effort. This relates to the difference between the level of skills is a mirror of what is done, while the level of effort is a mirror of what is done.

\section{c) Organizational Support}

In organizational support, the company provides facilities for employees including training and development, equipment and technology, performance standards, and management and partners. Performance is basically what employees do or don't do. Employee performance is what influences as much as they contribute to the organization.

\section{6) Elements of Performance Evaluation}

According to Mathis and Jackson (2006: 378), performance is basically what employees do. Employee performance that is common to most jobs includes the following elements:

- Quantity of results 
- Quality of results

- Timeliness of results

- Presence or absence

- Ability to work together.

\section{7) Definition of Employees}

Employees are people who work in an institution be it in an office, company, and so on, by getting a salary (wages). Employees can also be interpreted as humans who use their energy and ability to get a reward in the form of income in the form of money or other forms to employers or employers. Basically laborers, workers, laborers and employees are the same. But in Indonesian culture, "Labor" connotes as lowly, despicable, harsh workers and so on. Whereas workers, laborers and employees are the designation for higher workers, and tend to be given to workers who do not use muscles but the brain in doing work. However, in essence, these four words are the same and have the meaning of workers. This mainly refers to the Labor Law which applies generally to all workers and employers in Indonesia

\section{Research Methodology}

The method used is the library study method (library research) and field study (Field Research). The method of library study is by collecting data and studying various literatures in the form of books, lecture dictates and others as they relate to the problem being studied and discussed. While field studies by interview and questionnaire distribution. The population in this study is all employees who work as many as 50 people, and a sample of 20 people taken at random (random sampling)

The data analysis technique of 2 known research variables, namely the independent variable (X) / independent is the work environment and the $\mathrm{Y}$ variable (dependent) is the employee's performance, can be calculated using simple linear regression, correlation, determination coefficient, hypothesis testing

\section{Discussion}

In the results of this study the data obtained through questionnaires then conducted a discussion of the data obtained from 20 respondents after being processed with a Likert scale, which was taken at random. The results are: $\Sigma X=1227, \Sigma Y=1249, \Sigma X 2=50867, \Sigma Y 2=52573, \Sigma X Y=51525$. For simple linear regression analysis the results are: $\mathrm{b}=0.65 \mathrm{a}=5.21$, then $\mathrm{Y}=15.21+0.65 \mathrm{X}$. Simple Correlation Regression analysis results are to find out how much the calculation of the correlation coefficient of the influence of independent variables on the dependent variable, the result: $r=0.70$. Determination Coefficient Analysis Results namely the results of correlation analysis can be continued by calculating the coefficient of determination that is the value of $r$ arithmetic squared and multiplied by $100 \%, \mathrm{KD}=\mathrm{r} 2.100 \%=49.5 \%$. Hypothesis Testing is to determine the significance of the influence of the work environment on Employee Performance at PT. Abadi motor Indonesia, the results are $t$ count $=5.245$, while $t$ table with an error rate of $5 \%$ (0.05) sample of 20 people and the result is $t$ table $=2.048$, then $t$ count is greater than $t$ table then $\mathrm{Ha}$ is accepted and $\mathrm{H} 0$ is rejected, which means there is a significant influence between the work environment on Employee Performance at PT. Abadi Motor Indonesia. 


\section{Conclusions and Suggestions}

\subsection{Conclusions}

After processing and analyzing the data collected through statistical tests, the conclusion is as follows:

- The results of a simple linear regression analysis are $a=15.21$ and $b=0.65$. From the results of a simple linear regression analysis obtained the equation $\mathrm{Y}=15.21+0.43 \mathrm{X}$, where the ups and downs of the $\mathrm{Y}$ value is strongly influenced by the magnitude of the $\mathrm{X}$ value

- The results of the product moment correlation coefficient (r) from the statistical calculation obtained $\mathrm{r}=0.70$ which means that the influence of the work environment on the performance of employees at PT Abadi Motor Indonesia is positive and strong.

- Determination Coefficient (KD) of $49.5 \%$ means that it can be seen that the work environment affects employee performance by $49.5 \%$, the remaining $50.5 \%$ is influenced by other variables not included in this study.

- In testing the research hypothesis obtained $r$ count value of 5.245 is greater than $t$ table 2.048 with an error rate of $5 \%(0.05)$ this means that according to the terms of the hypothesis test such results are Ha accepted and $\mathrm{H} 0$ rejected.

\subsection{Suggestions}

Based on research results the influence of the work environment on employee performance has a positive and significant impact on employees in carrying out their duties, then:

- The work environment must be able to create good working conditions which will greatly affect employee performance.

- The work environment needs to be maintained cleanliness, tidiness, comfort in order to provide work motivation for employees so that employee performance increases.

\section{References}

[1] Decenzo, David A., Robbins, Stephen P. (1999). Human Resources, New York: John Willey and Sons, Inc

[2] Gibson Ivansevich and Danelly, 1995, Organization, Behavior, Structure, Process, volume 2 Jakarta, Binarupa Aksara.

[3] Handoko, TH, 2001 Personnel and Human Resources management, 2nd edition, Yogyakarta, PBFE

[4] Hasibuan, Melayu S.P, 2001, organization and motivation, Jakarta, PT Bumi Aksara

[5] Hasibuan, Melayu S.P, 2007, Human Resources Management, ninth edition, Jakarta, PT Bumi Aksara,

[6] Kartono, Kartini, 2009, Leaders and Leadership, Jakarta, Rajawali Press.

[7] Mangkunegara, A.A Anwar Prabu, 2000, Human Resource Management, Bandung, PT Youth Rosdakarya.

[8] Mathis, Robert and Jackson, Jaka H, 2001, Management of Human Resources, Book I, Jakarta, Salemba four.

[9] Bagus Kisworo. (2012). The Relationship of Motivation, Discipline, and Work Circles to the Productivity of Educators and Education Workers at the Central Java Semarang Ex-residency Learning Activity Center. Thesis. UNY. 
[10] Liang Gie. (1996). Modern Office Administration. Yogjakarta: Liberty Yogjakarta.

[11] Badri Munir Sukoco. (2006). Modern Office Administration Management. Surabaya: Erlangga.

[12] Decree of the Minister of Health of the Republic of Indonesia Number 1405 / MENKES / SK / XI / 2002 concerning health requirements for Office and Industrial Work Circles.

[13] Wursanto, 2007, Fundamentals of Organizational Sciences, Yogyakarta, Andi. 18

*Corresponding author.

E-mail address: agus_jamaludin63@yahoo.co.id 